\title{
IMPROVEMENT OF NUTRITIONAL VALUE FOR DATE PALM LEAVES USING UREA TREATMENT AND ITS EFFECT ON SMALL RUMINANTS FEEDING.
}

\author{
Hend A. Aziz \\ Animal Nutrition Department, Desert Research Center, Cairo, Egypt.
}

(Received 8/10/2019, accepted 14/11/2019)

\section{SUMMARY}

\begin{abstract}
$\mathrm{P}$ urpose of this study was to evaluate the effect of replacing alfalfa hay with date palm tree leaves (DPL) untreated or treated with urea in diets and study its effect on sheep feeding. The effect of using urea with different levels $(4,6$ and $8 \%$ ) on chemical composition and fiber constituents of date palm leaves was studied in laboratory experiment; also, four rations included different ratios of date palm leaves $(15,25,35$ and $50 \%)$ were carried out to choose two of them. Then the chosen two ratios of DPL were used to study the effect of the three levels of urea on the chemical composition and in vitro nutrients disappearance of these ratios. Then the perfect ratio of DPL treated with different urea levels used to study its effect on sheep performance, the rations were: C: ration contains $50 \% \mathrm{CFM}+50 \%$ berseem hay $\mathrm{BH}$ (control). R (1): control replaced by $35 \%$ DPL. R (2): control replaced by $35 \%$ untreated DPL (4\% urea). R (3): control replaced by $35 \%$ DPL (6\% urea) and R (4): control replaced by 35\% DPL (8\% urea). Main results indicated that urea treatment improved chemical composition of DPL compared with untreated as CP content increased while $\mathrm{CF}$ and its fractions decreased $(\mathrm{P} \leq 0.01)$. The enhancement in $\mathrm{CP}, \mathrm{CF}$, cellulose and hemicellulose contents and the improvement of nutrients disappearance for rations contained 35\% DPL treated with urea $(4,6$ and $8 \%$ ) suggested using these rations in digestibility trial which indicated significant increase $(\mathrm{P} \leq 0.01)$ for digestibility coefficients, nutritive values, nitrogen balance and rumen fermentations and microbes compared to untreated ration. Also, treated rations significantly $(\mathrm{P} \leq 0.01)$ enhanced serum total proteins and albumin concentrations more than control and untreated rations, although they increased urea concentration.
\end{abstract}

Keywords: date palm leaves, digestibility, rumen fermentations, sheep and urea treatment.

\section{INTRODUCTION}

In Sinai where livestock depend mainly upon grazing of natural pastures, animals suffer from a shortage of feed during most of the year. In such areas, the possibility of using agro-industrial byproducts as a part of concentrate mixture, in addition to the native range forages is of more than passing interest. The use of crop residues for ruminant feeding is essentially constrained by its low digestibility and voluntary intake, so that energy requirements for maintenance are not satisfied when it is given as the only feed to animals. Large areas are cultivated by date palm trees, especially in Sinai and the other zones, therefore, there are great amounts of date palm trees by-products without beneficial usage and are considered as wastes. This allows obtaining a good quality of forage all the year around and it allows using date palm leaves for feeding instead of being burned and causing pollution. Bahman et al. (1997) suggested that date palm leaves might be an acceptable alternative to barley straw in highly concentrated diets for dairy cows.

As a solution for the shortage of animal feeds scientists suggested the use of urea to increase the crude protein contents of roughages, to improve their nutrients digstibilities (Shoukry, 1992; Shoukry et al., 1992 and Fouad et al., 1998). Urea treatment is the most chemical applicable methods used for upgrading nutritive value of roughages. The alkali treatment is known to be a powerful swelling agent for cellulose, hemicellulose and lignin as it leads to reactions which may be responsible for the reduction in molecular weight and solubilization of lignin protein (Chesson et al., 1983). Chemical treatment may improve the chemical composition of roughage depending on the type of chemical, concentration, duration of treatment, volume of used water and temperature of treatment, rather than the nature of roughage itself (Abou-Hussein et al., 1982). Urea, $\mathrm{CO}\left(\mathrm{NH}_{2}\right)_{2}$, contains $46.6 \% \mathrm{~N}$, one pound of urea furnishing as much $\mathrm{N}$ as 6.77 pounds of $43 \%$ protein cotton seed meal (CSM). Until recent years, experimental evidence was 
inconclusive as to the ability of ruminants to utilize urea and other simple nitrogen carrying compounds. These simple nitrogen compounds when fed in sufficient amount to balance low-protein rations apparently had no detrimental effect on the animals.

The purpose of present study was to evaluate the effect of replacing alfalfa hay with untreated date palm tree leaves or treated with different concentrations of urea in diets and study its effect on sheep feeding.

\section{MATERIALS AND METHODS}

The field experiments were carried out at Ras Sudr Experimental Research Station, Desert Research Center, located in Southern Sinai Governorate in 2018. Laboratory, in vitro and in vivo experiments were designed to study the effect of feeding different ratios of date palm leaves treated with different levels of urea. Date palm leaves were pruning and chopped to $2-3 \mathrm{~cm}$ then air-dried for 15 days to reach $10-15 \%$ moisture then packed till used.

\section{Laboratory experiment:}

The effect of using urea with different levels on chemical composition and fiber constituents of date palm leaves was studied in laboratory experiment; also, four rations included different ratios of date palm leaves were carried out to choose two of them that give a good chemical composition with low costs, the experimental treatments were as follow:

T (1): Untreated date palm leaves (DPL). T (2): DPL treated with $4 \%$ urea. T (3): DPL treated with 6\% urea. T (4): DPL treated with $8 \%$ urea. R (1): ration contains $50 \%$ concentrate feed mixture (CFM) $+15 \%$ $\mathrm{DPL}+35 \%$ berseem hay $(\mathrm{BH})$. $\mathrm{R}(2)$ : ration contains $50 \% \mathrm{CFM}+25 \% \mathrm{DPL}+25 \% \mathrm{BH}$. $\mathrm{R}$ (3): ration contains $50 \% \mathrm{CFM}+35 \% \mathrm{DPL}+15 \% \mathrm{BH}$. $\mathrm{R}(4)$ : ration contains $50 \% \mathrm{CFM}+50 \% \mathrm{DPL}$

Air-dried chopped date palm leaves $(500 \mathrm{~g})$ were moistened for $40 \%$ and sprayed with urea at levels of $4 \%, 6 \%$ and $8 \%$ plus molasses solution (which was calculated to provide $10 \%$ from the dry matter as a common energy source in ensiled mixture). Then the mixture put in plastic bag and kept closed for 21 days then bags were opened and oven dried at $70{ }^{\circ} \mathrm{C}$ for chemical analysis.

\section{In vitro experiment:}

The two ratios of DPL which were choose from laboratory experiment were used to study the effect of the three levels of urea on the chemical composition and in vitro nutrients disappearance of these ratios as follow:

$\mathrm{R}$ (1): ration contains $50 \% \mathrm{CFM}+35 \% \mathrm{DPL}$ treated with $4 \%$ urea $+15 \% \mathrm{BH}$.

$\mathrm{R}(2)$ : ration contains $50 \% \mathrm{CFM}+35 \% \mathrm{DPL}$ treated with $6 \%$ urea $+15 \% \mathrm{BH}$.

$\mathrm{R}$ (3): ration contains $50 \% \mathrm{CFM}+35 \% \mathrm{DPL}$ treated with $8 \%$ urea $+15 \% \mathrm{BH}$.

$\mathrm{R}$ (4): ration contains $50 \% \mathrm{CFM}+50 \%$ DPL treated with $4 \%$ urea.

$\mathrm{R}(5)$ : ration contains $50 \% \mathrm{CFM}+50 \% \mathrm{DPL}$ treated with $6 \%$ urea.

$\mathrm{R}(6)$ : ration contains $50 \% \mathrm{CFM}+50 \%$ DPL treated with $8 \%$ urea.

Three tubes as replicates for each ration were incubated for 24 hours with ruminal fluid collected two hours post feeding from six male sheep fed concentrate feed mixture and good quality BH to estimated DM, OM and other nutrients disappearance according to the method reported by Norris (1976).

\section{In vivo experiment:}

The perfect ratio of DPL treated with different urea levels was choose to study the effect of feeding control, untreated and treated DPL on sheep digestibility coefficients, ruminal fermentations, microbes counts and some blood parameters. The carried out experimental rations were:

C: ration contains $50 \% \mathrm{CFM}+50 \% \mathrm{BH}$ (control).

$\mathrm{R}$ (1): ration contains $50 \% \mathrm{CFM}+35 \%$ untreated $\mathrm{DPL}+15 \% \mathrm{BH}$.

$\mathrm{R}$ (2): ration contains $50 \% \mathrm{CFM}+35 \% \mathrm{DPL}$ treated with $4 \%$ urea $+15 \% \mathrm{BH}$.

$\mathrm{R}(3)$ : ration contains $50 \% \mathrm{CFM}+35 \% \mathrm{DPL}$ treated with $6 \%$ urea $+15 \% \mathrm{BH}$.

$\mathrm{R}$ (4): ration contains $50 \% \mathrm{CFM}+35 \%$ DPL treated with $8 \%$ urea $+15 \% \mathrm{BH}$. 
The digestibility experiment was lasted for 50 days. Twenty adult Barki male sheep (four animals for each treatment) were fed on experimental rations for 30 days as a palatability and adaptation period for treatments. Then rams were placed in metabolic cages for 20 days from which the first 15 days were considered as an adaptation and preliminary period, followed by 5 days as collection period. Over the collection period, daily amount of feed consumed, residuals, feces and urine were estimated for each animal.

\section{Proximate analysis:}

The proximate analysis for feeds, feces and urine were determined according to the AOAC (1995). Neutral detergent fiber (NDF), acid detergent fiber (ADF) and acid detergent liginin (ADL) were determined according to the procedure of Van Soest (1994).

\section{Rumen liquor parameters:}

Rumen liquor samples were obtained at 0,4 and 8 hours post feeding. $\mathrm{pH}$ was immediately measured using a digital $\mathrm{pH}$ meter. AOAC (1995) methods used to determine total nitrogen (TN), ammonia and non-protein nitrogen concentrations (NPN), true protein nitrogen was calculated (TN-NPN). Total volatile fatty acids were estimated according to Warner (1964). The method described by Ogimoto and Imai (1981) used to determine ruminal ciliate protozoa count. The description by Dehority (1993) used to publish the identification of genera and species.

\section{Blood sampling:}

Before morning feeding and 4 hours post-feeding the samples of blood were collected. Total protein analyzed according to method of Armstrong and Carr (1964), albumin according to Doumas and Biggs (1971), globulin was calculated by subtracting, urea according to Patton and Crouch (1977). Aspartate aminotransferase (AST) and alanine aminotransferase (ALT) according to Wikison et al. (1972).

\section{Statistical analysis:}

Statistical analysis system of SAS (2004) used to statistical analysis of data, chemical composition, cell wall constituents analysis (two replicates of samples for each item were used), nutrients disappearance, digestibility coefficients and nitrogen utilization were analyzed by one-way analysis and the model was: $\mathrm{Yij}=\mu+\mathrm{Ti}+$ eij. The used design for rumen fermentations, rumen microbes and blood parameters was two-way analysis, the model was: $Y_{i j}=\mu+T_{i}+I_{j}+T_{i j}+e_{i j}$.

Where: - $Y_{i j}=$ experimental observation, $\mu=$ general mean. $T_{i}=$ effect of treatment (i=1:5), $I_{j}=$ effect of sampling time $(\mathrm{j}=0,4$ and 8$)$. $\mathrm{TI}_{\mathrm{ij}}=$ effect of interaction of treatment and sampling time and $\mathrm{e}_{\mathrm{ij}}=$ experimental error.

Duncan's multiple test used to carry out the separation among means (Duncan, 1955).

\section{RESULTS AND DISCUSSION}

\section{Laboratorial experiment:}

The data represented in Table (1) showed that $\mathrm{T} 4, \mathrm{~T} 3$ and $\mathrm{T} 2$, respectively increased $(\mathrm{P} \leq 0.01)$ the values of DM, OM, EE, NFE, CP and cellulose more than untreated DPL (T1). While, the same treatments decreased $(\mathrm{P} \leq 0.01)$ the values of ash, $\mathrm{CF}, \mathrm{NDF}, \mathrm{ADF}, \mathrm{ADL}$, and hemicellulose more than UDPL. It is clear that T4 (8\%) increased CP and cellulose contents more than other treatments, although, it had the most decrease for CF, NDF, ADF, ADL, and hemicellulose contents, also, T3 (6\%) was better than T2 (4\%). The increase in CP content with urea treatment was about 3.01, 4.19 and 6.05 for T2, T3 and T4 more than T1. An agreement results reported by Naqadi et al. (2006) who found that treating DPL with $3 \%$ urea increased $\mathrm{EE}$ and $\mathrm{CP}$ content while it decreased $\mathrm{CF}$ content.

Ratios of 50\% (R4) and 35\% (R3) increased ( $\mathrm{P} \leq 0.01) \mathrm{DM}, \mathrm{OM}, \mathrm{CF}$ and $\mathrm{ADL}$ contents, while, the ratios of $15 \%(\mathrm{R} 1)$ and $25 \%(\mathrm{R} 2)$ increased ash, EE, CP, NFE and cellulose contents, although the difference among all ratios was not significant $(\mathrm{P} \leq 0.01)$ for $\mathrm{NDF}, \mathrm{ADF}$ and hemicellulose. It was clear that $\mathrm{CP}$ content decreased while CF content increased as the ratio of DPL increased in the ration. But the difference in $\mathrm{CP}$ and $\mathrm{CF}$ contents among the four rations was considered acceptable as that R1 increased in $\mathrm{CP}$ content by 1.54 and 2.81 but it decreased in CF content by 3.14 and 5.56 from R3 and R4, respectively. So the ratios 35 and 50\% of DPL had good chemical composition and might reduce the costs of nutrition that encouraged using these ratios in in vitro experiments. 
Table (1): Effect of urea and different ratios of DPL on chemical composition (\%) during laboratorial experiment.

\begin{tabular}{lcccccccccc}
\hline & & \multicolumn{4}{c}{ Urea concentration } & \multicolumn{4}{c}{ DPL ratio } \\
\cline { 2 - 10 } Item & UDPL & $4 \%$ & $6 \%$ & $8 \%$ & & $15 \%$ & $25 \%$ & $35 \%$ & $50 \%$ \\
\hline DM & T1 & T2 & T3 & T4 & \pm SE & R1 & R2 & R3 & R4 & \pm SE \\
OM & $93.23^{\mathrm{b}}$ & $93.87^{\mathrm{a}}$ & $94.00^{\mathrm{a}}$ & $94.18^{\mathrm{a}}$ & 0.230 & $92.67 \mathrm{c}$ & $92.86^{\mathrm{bc}}$ & $93.08^{\mathrm{b}}$ & $93.40^{\mathrm{a}}$ & 0.320 \\
Ash & $90.45^{\mathrm{c}}$ & $91.57^{\mathrm{b}}$ & $91.75^{\mathrm{ab}}$ & $92.04^{\mathrm{a}}$ & 0.116 & $90.35^{\mathrm{c}}$ & $90.60^{\mathrm{bc}}$ & $90.88^{\mathrm{b}}$ & $91.24^{\mathrm{a}}$ & 0.230 \\
EE & $9.55^{\mathrm{a}}$ & $8.43^{\mathrm{b}}$ & $8.25^{\mathrm{c}}$ & $7.96^{\mathrm{d}}$ & 0.425 & $9.65^{\mathrm{a}}$ & $9.40^{\mathrm{b}}$ & $9.12^{\mathrm{c}}$ & $8.76^{\mathrm{d}}$ & 0.349 \\
$\mathrm{CP}$ & $1.33^{\mathrm{c}}$ & $1.52^{\mathrm{b}}$ & $1.64^{\mathrm{ab}}$ & $1.70^{\mathrm{a}}$ & 0.117 & $2.56^{\mathrm{a}}$ & $2.43^{\mathrm{ab}}$ & $2.32^{\mathrm{b}}$ & $2.15^{\mathrm{c}}$ & 0.193 \\
$\mathrm{CF}$ & $5.81^{\mathrm{d}}$ & $8.82^{\mathrm{c}}$ & $10.00^{\mathrm{b}}$ & $11.86^{\mathrm{a}}$ & 0.252 & $11.90^{\mathrm{a}}$ & $11.12^{\mathrm{b}}$ & $10.36^{\mathrm{c}}$ & $9.09^{\mathrm{d}}$ & 0.343 \\
NFE & $42.26^{\mathrm{a}}$ & $29.82^{\mathrm{b}}$ & $19.23^{\mathrm{c}}$ & $18.36^{\mathrm{d}}$ & 0.343 & $21.18^{\mathrm{d}}$ & $22.77^{\mathrm{c}}$ & $24.32^{\mathrm{b}}$ & $26.74^{\mathrm{a}}$ & 0.541 \\
NDF & $41.05^{\mathrm{d}}$ & $51.41^{\mathrm{c}}$ & $60.88^{\mathrm{a}}$ & $60.12^{\mathrm{b}}$ & 0.145 & $54.71^{\mathrm{a}}$ & $54.28^{\mathrm{ab}}$ & $53.88^{\mathrm{bc}}$ & $53.26^{\mathrm{c}}$ & 0.219 \\
$\mathrm{ADF}$ & $60.32^{\mathrm{a}}$ & $47.86^{\mathrm{b}}$ & $44.91^{\mathrm{c}}$ & $42.47^{\mathrm{d}}$ & 0.116 & $46.30^{\mathrm{a}}$ & $46.10^{\mathrm{a}}$ & $45.85^{\mathrm{ab}}$ & $45.54^{\mathrm{b}}$ & 0.084 \\
$\mathrm{ADL}$ & $43.35^{\mathrm{a}}$ & $34.87^{\mathrm{b}}$ & $32.92^{\mathrm{c}}$ & $31.68^{\mathrm{d}}$ & 0.581 & 30.53 & 30.47 & 30.44 & 30.36 & 0.265 \\
Cellulose & $22.90^{\mathrm{a}}$ & $13.32^{\mathrm{b}}$ & $10.28^{\mathrm{c}}$ & $8.19^{\mathrm{d}}$ & 0.252 & $9.76^{\mathrm{d}}$ & $11.36^{\mathrm{c}}$ & $12.95^{\mathrm{b}}$ & $15.30^{\mathrm{a}}$ & 0.346 \\
Hemicellulose & $20.45^{\mathrm{d}}$ & $21.55^{\mathrm{c}}$ & $22.64^{\mathrm{b}}$ & $23.49^{\mathrm{a}}$ & 0.335 & $20.77^{\mathrm{a}}$ & $19.11^{\mathrm{b}}$ & $17.49^{\mathrm{c}}$ & $15.06^{\mathrm{d}}$ & 0.329 \\
\hline
\end{tabular}

Means with different letters with each row are significantly different $(P \leq 0.01)$.

T(1): Untreated date palm leaves (DPL). T(2): DPL treated with 4\% urea. T (3): DPL treated with 6\% urea.

$T$ (4): DPL treated with $8 \%$ urea. $R(1)$ : ration contains $50 \%$ concentrate feed mixture $(C F M)+15 \%$ DPL $+35 \%$

berseem hay $(B H) . R(2):$ ration contains $50 \% C F M+25 \% D P L+25 \% B H . R(3):$ ration contains $50 \% C F M+35 \%$

$D P L+15 \%$ BH and $R(4)$ : ration contains $50 \% C F M+50 \%$ DPL.

\section{In vitro experiments:}

\section{Chemical composition and cell wall constituents of feedstuffs:}

The effect of urea on rations contained 35 and 50\% DPL (Table 2) showed that urea concentrations (4, 6 and $8 \%)$ had no effect $(\mathrm{P} \leq 0.01)$ on $\mathrm{DM}$ and $\mathrm{OM}$ content for the two ratios of DPL. Ash and EE contents were not significantly $(\mathrm{P} \leq 0.01)$ differed among all rations. $\mathrm{CP}, \mathrm{CF}, \mathrm{NFE} \mathrm{NDF}, \mathrm{ADF}, \mathrm{ADL}$, cellulose and

Table (2): Chemical composition (\%) of rations contain different ratios of DPL treated with different concentrations of urea during in vitro experiment.

\begin{tabular}{|c|c|c|c|c|c|c|c|}
\hline \multirow[b]{3}{*}{ Item } & \multicolumn{3}{|c|}{$35 \%$ DPL } & \multicolumn{3}{|c|}{$50 \%$ DPL } & \\
\hline & \multicolumn{6}{|c|}{ Urea concentration } & \\
\hline & $4 \%$ & $6 \%$ & $8 \%$ & $4 \%$ & $6 \%$ & $8 \%$ & \\
\hline & R1 & $\mathrm{R} 2$ & R3 & R4 & R5 & R6 & $\pm \mathrm{SE}$ \\
\hline DM & 93.32 & 93.36 & 93.41 & 93.72 & 93.76 & 93.87 & 0.031 \\
\hline $\mathrm{OM}$ & 91.25 & 91.32 & 91.42 & 91.97 & 91.88 & 92.02 & 0.029 \\
\hline Ash & $8.75^{\mathrm{a}}$ & $8.68^{a}$ & $8.58^{\mathrm{a}}$ & $8.22^{\mathrm{ab}}$ & $8.12^{\mathrm{ab}}$ & $7.98^{b}$ & 0.018 \\
\hline $\mathrm{EE}$ & $2.42^{\mathrm{a}}$ & $2.46^{\mathrm{a}}$ & $2.47^{\mathrm{a}}$ & $2.26^{\mathrm{b}}$ & $2.32^{\mathrm{b}}$ & $2.35^{\mathrm{b}}$ & 0.021 \\
\hline $\mathrm{CP}$ & $11.37^{\mathrm{d}}$ & $11.79^{c}$ & $12.40^{\mathrm{a}}$ & $10.6^{\mathrm{f}}$ & $11.18^{\mathrm{e}}$ & $12.11^{\mathrm{b}}$ & 0.011 \\
\hline $\mathrm{CF}$ & $16.30^{\mathrm{c}}$ & $15.24^{\mathrm{e}}$ & $14.79^{\mathrm{f}}$ & $18.52^{\mathrm{a}}$ & $16.97^{\mathrm{b}}$ & $15.99^{\mathrm{d}}$ & 0.011 \\
\hline NFE & $57.49^{\mathrm{e}}$ & $60.77^{\mathrm{c}}$ & $60.56^{c}$ & $58.40^{\mathrm{d}}$ & $63.14^{\mathrm{a}}$ & $62.77^{\mathrm{b}}$ & 0.016 \\
\hline NDF & $41.50^{\mathrm{a}}$ & $40.48^{b}$ & $39.63^{c}$ & $39.31^{\mathrm{d}}$ & $37.84^{\mathrm{e}}$ & $36.61^{\mathrm{f}}$ & 0.027 \\
\hline $\mathrm{ADF}$ & $27.45^{\mathrm{a}}$ & $26.75^{b}$ & $26.34^{\mathrm{bc}}$ & $26.11^{\mathrm{c}}$ & $25.15^{\mathrm{d}}$ & $24.51^{\mathrm{e}}$ & 0.022 \\
\hline ADL & $9.61^{\mathrm{b}}$ & $8.52^{\mathrm{d}}$ & $7.80^{\mathrm{f}}$ & $10.53^{\mathrm{a}}$ & $9.00^{c}$ & $7.97^{\mathrm{e}}$ & 0.024 \\
\hline Cellulose & $17.84^{\mathrm{c}}$ & $18.23^{\mathrm{b}}$ & $18.54^{\mathrm{a}}$ & $15.58^{f}$ & $16.15^{\mathrm{e}}$ & $16.54^{\mathrm{d}}$ & 0.010 \\
\hline Hemicellulose & $14.05^{\mathrm{a}}$ & $13.73^{\mathrm{b}}$ & $13.29^{\mathrm{c}}$ & $13.20^{\mathrm{c}}$ & $12.69^{\mathrm{d}}$ & $12.10^{\mathrm{e}}$ & 0.013 \\
\hline
\end{tabular}

Means with different letters with each row are significantly different $(P \leq 0.01)$.

$R(1)$ : ration contains $50 \% C F M+35 \%$ DPL treated with $4 \%$ urea $+15 \%$ BH. $R(2)$ : ration contains $50 \% C F M$ $+35 \%$ DPL treated with $6 \%$ urea $+15 \%$ BH. $R(3):$ ration contains $50 \% C F M+35 \%$ DPL treated with $8 \%$ urea $+15 \%$ BH. $R(4)$ : ration contains $50 \%$ CFM $+50 \%$ DPL treated with $4 \%$ urea. $R(5)$ : ration contains $50 \% C F M$ $+50 \%$ DPL treated with $6 \%$ urea and $R(6)$ : ration contains $50 \%$ CFM $+50 \%$ DPL treated with $8 \%$ urea.

hemicellulose Contents indicated significant difference $(\mathrm{P} \leq 0.01)$ among rations. R3 had the highest $(\mathrm{P} \leq 0.01) \mathrm{CP}$ content followed by R6. The lowest CF content was for R3 followed by R2, while R4 was 
the highest one among all treatments. R3, R2 and R1decreased ADL content and enhanced the contents of cellulose and hemicellulose and ADL. This indicated that ration contained 35\% DPL treated with different concentrations of urea enhanced $\mathrm{CP}$ and $\mathrm{CF}$ contents.

\section{In vitro nutrients disappearance:}

The inserted data in Table (3) showed significant $(\mathrm{P} \leq 0.01)$ differences among all rations on nutrients disappearance. The best disappearance of DM, OM, EE, CP, CF, NFE, NDF, ADF, ADL, cellulose and hemicellulose was for rations contained $35 \%$ DPL treated with different concentrations of urea. The ratio $35 \%$ significantly $(\mathrm{P} \leq 0.01)$ increased nutrients disappearance more than the ratio $50 \%$, while $8 \%$ urea concentration was the highest $(\mathrm{P} \leq 0.01)$ nutrients disappearance. Similar results were obtained by Phillip et al. (2014) who reported that degradation of DM, OM, CP and other nutrients were significantly increased when roughage treated with urea compared with control. The enhancement in $\mathrm{CP}$ and $\mathrm{CF}$ contents and nutrients disappearance with rations contained 35\% DPL treated with different urea concentrations suggested using these rations in digestibility trial.

Table (3): Nutrients disappearance (\%) of rations contains different ratios of DPL treated with different levels of urea during in vitro experiment.

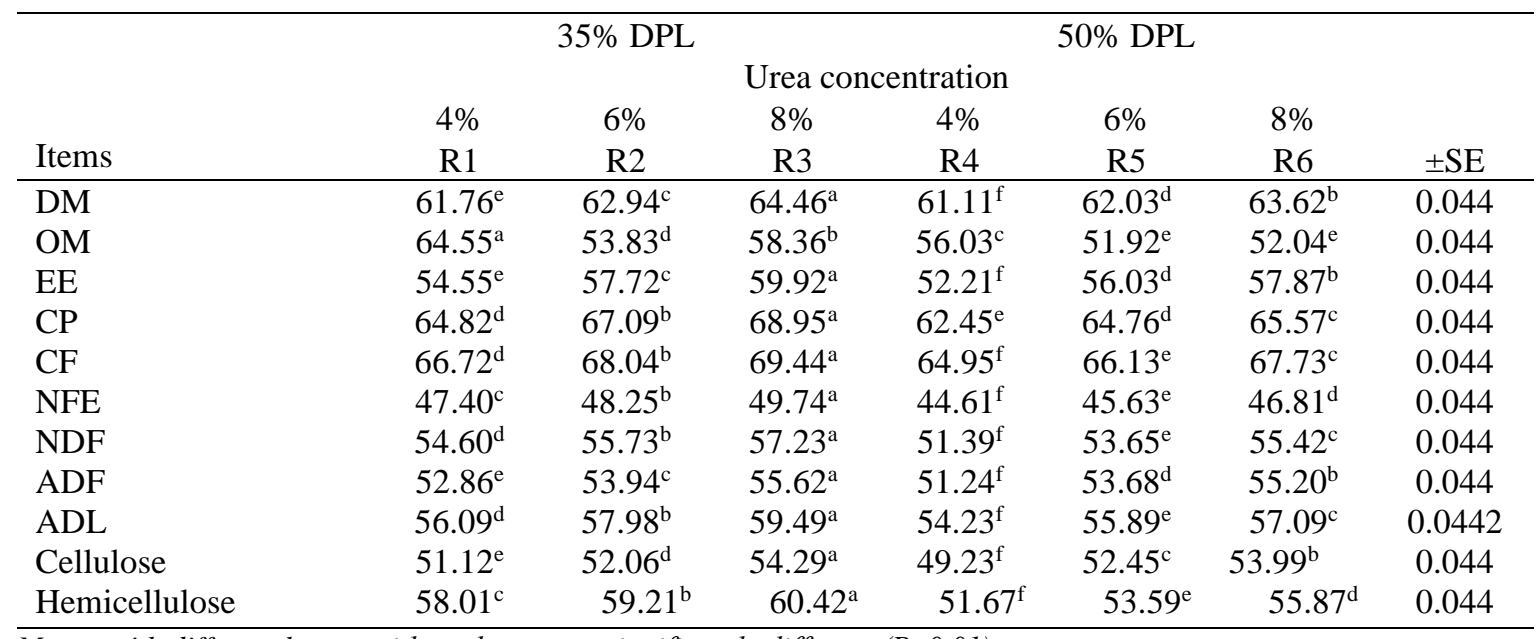

Means with different letters with each row are significantly different $(P \leq 0.01)$.

\section{In vivo experiments:}

\section{Chemical composition and cell wall constituents of feedstuffs:}

The data of Table (4) indicated that ration contains ureated DPL enhanced ( $\mathrm{P} \leq 0.01) \mathrm{DM}, \mathrm{OM}, \mathrm{EE}$, $\mathrm{CP}, \mathrm{NFE}$ and cellulose contents more than untreated ration, although ureated rations decreased $(\mathrm{P} \leq 0.01)$ ash, $\mathrm{CF}, \mathrm{NDF}, \mathrm{ADF}, \mathrm{ADL}$ and hemicellulose contents more than untreated ration, also ureated rations decreased $(\mathrm{P} \leq 0.01)$ ash, $\mathrm{CF}, \mathrm{NDF}, \mathrm{ADF}$ and $\mathrm{ADL}$ contents more than control ration, which means that the experimental ureated rations had good chemical composition.

Similar trend of results were obtained by Mohamed et al. (1998) and Koening and Beauchemin (2005) who reported that urea supplementation in diets increased CP content and digestibility. Also, Aziz (2009) found that olive tree by-products treated with $4 \%$ urea increased DM, OM, EE and CP content and decreased $\mathrm{CF}, \mathrm{NDF}, \mathrm{ADF}, \mathrm{ADL}$, cellulose and hemicellulose content compared to control group in sheep. Moreover, Okab et al. (2012) reported that OM, EE, CF, NDF, ADF, ADL, cellulose and hemicellulose contents were improved in ration contains $50 \%$ CFM+50\% DPL treated with $4 \%$ urea more than untreated and control groups.

\section{Dry matter intake, digestibility coefficients and nutritive values:}

Data of Table (5) indicated that body weight was almost the same for animals fed the five rations. Dry matter intake was not significantly differed $(\mathrm{P} \leq 0.01)$ among $\mathrm{R} 2, \mathrm{R} 3, \mathrm{R} 4$ and $\mathrm{C}$ groups where $\mathrm{R} 4$ was the highest one, while R1 had the lowest $(\mathrm{P} \leq 0.01)$ DMI. The increment in DMI may be due to good palatability of ureated rations more than untreated ration. 
Table (4): Chemical composition of control and rations contains untreated and ureated DPL during in vivo experiments.

\begin{tabular}{lcccccccc}
\hline & \multicolumn{7}{c}{ Experimental ration } & \\
\cline { 2 - 7 } Item & CFM & Hay & C & R1 & R2 & R3 & R4 & \\
\hline DM & 93.56 & 91.11 & $92.34^{\mathrm{c}}$ & $93.08^{\mathrm{b}}$ & $93.32^{\mathrm{a}}$ & $93.36^{\mathrm{a}}$ & $93.41^{\mathrm{a}}$ & 0.013 \\
OM & 91.88 & 87.89 & $90.01^{\mathrm{c}}$ & $90.88^{\mathrm{b}}$ & $91.25^{\mathrm{a}}$ & $91.32^{\mathrm{a}}$ & $91.42^{\mathrm{a}}$ & 0.008 \\
Ash & 8.12 & 12.11 & $10^{\mathrm{a}}$ & $9.12^{\mathrm{b}}$ & $8.75^{\mathrm{c}}$ & $8.68^{\mathrm{c}}$ & $8.58^{\mathrm{c}}$ & 0.010 \\
EE & 3.00 & 2.48 & $2.74^{\mathrm{a}}$ & $2.32^{\mathrm{c}}$ & $2.42^{\mathrm{b}}$ & $2.46^{\mathrm{b}}$ & $2.47^{\mathrm{b}}$ & 0.073 \\
CP & 12.37 & 13.88 & $13.13^{\mathrm{a}}$ & $10.36^{\mathrm{e}}$ & $11.37^{\mathrm{d}}$ & $11.79^{\mathrm{c}}$ & $12.40^{\mathrm{b}}$ & 0.021 \\
CF & 11.21 & 26.39 & $18.8^{\mathrm{b}}$ & $24.32^{\mathrm{a}}$ & $16.30^{\mathrm{c}}$ & $15.24^{\mathrm{d}}$ & $14.79^{\mathrm{e}}$ & 1.396 \\
NFE & 65.30 & 45.14 & $55.34^{\mathrm{c}}$ & $53.88^{\mathrm{d}}$ & $57.49^{\mathrm{b}}$ & $60.77^{\mathrm{a}}$ & $60.56^{\mathrm{a}}$ & 0.018 \\
NDF & 30.76 & 62.54 & $46.65^{\mathrm{a}}$ & $45.85^{\mathrm{b}}$ & $41.50^{\mathrm{c}}$ & $40.48^{\mathrm{d}}$ & $39.63^{\mathrm{e}}$ & 0.883 \\
ADF & 17.34 & 43.86 & $30.6^{\mathrm{a}}$ & $30.44^{\mathrm{a}}$ & $27.45^{\mathrm{b}}$ & $26.75^{\mathrm{c}}$ & $26.34^{\mathrm{c}}$ & 0.576 \\
ADL & 7.74 & 7.08 & $7.41^{\mathrm{d}}$ & $12.95^{\mathrm{a}}$ & $9.61^{\mathrm{b}}$ & $8.52^{\mathrm{c}}$ & $7.80^{\text {cd }}$ & 0.167 \\
Cellulose & 9.60 & 36.78 & $23.19^{\mathrm{a}}$ & $17.49^{\mathrm{d}}$ & $17.84^{\mathrm{c}}$ & $18.23^{\mathrm{bc}}$ & $18.54^{\mathrm{b}}$ & 0.022 \\
Hemicellulose & 13.42 & 18.68 & $16.05^{\mathrm{a}}$ & $15.41^{\mathrm{b}}$ & $14.05^{\mathrm{c}}$ & $13.73^{\mathrm{cd}}$ & $13.29^{\mathrm{d}}$ & 0.029 \\
\hline
\end{tabular}

Means with different letters with each row are significantly different $(P \leq 0.01)$.

$C$ : ration contains $50 \% C F M+50 \% B H($ control). $R(1)$ : ration contains $50 \% C F M+35 \%$ untreated DPL $+15 \%$ $B H . R(2)$ : ration contains $50 \% C F M+35 \%$ DPL treated with $4 \%$ urea $+15 \%$ BH. $R(3):$ ration contains $50 \%$ $C F M+35 \%$ DPL treated with $6 \%$ urea $+15 \%$ BH. $R(4)$ : ration contains $50 \%$ CFM $+35 \%$ DPL treated with $8 \%$ urea $+15 \% \mathrm{BH}$

Table (5): Nutrient digestibility and nutritive value of experimental rations fed for sheep groups.

\begin{tabular}{|c|c|c|c|c|c|c|}
\hline \multirow[b]{2}{*}{ Item } & \multicolumn{5}{|c|}{ Experimental ration } & \multirow[b]{2}{*}{$\pm \mathrm{SE}$} \\
\hline & $\mathrm{C}$ & $\mathrm{R} 1$ & $\mathrm{R} 2$ & R3 & $\mathrm{R} 4$ & \\
\hline Number of animals & 4 & 4 & 4 & 4 & 4 & \\
\hline Live body weight & 49.00 & 49.20 & 49.10 & 48.87 & 48.95 & 1.036 \\
\hline DM intake $\mathrm{g} / \mathrm{h} / \mathrm{d}$ & $946.63^{\mathrm{a}}$ & $862.85^{\mathrm{b}}$ & $944.51^{\mathrm{a}}$ & $995.45^{\mathrm{a}}$ & $958.03^{\mathrm{a}}$ & 15.737 \\
\hline \multicolumn{7}{|l|}{ Digestibility\%: } \\
\hline DM & $70.55^{\mathrm{a}}$ & $62.75^{\mathrm{b}}$ & $69.80^{\mathrm{a}}$ & $70.67^{\mathrm{a}}$ & $70.71^{\mathrm{a}}$ & 0.479 \\
\hline $\mathrm{OM}$ & $70.80^{\mathrm{a}}$ & $65.20^{\mathrm{b}}$ & $70.30^{\mathrm{a}}$ & $71.75^{\mathrm{a}}$ & $71.36^{\mathrm{a}}$ & 0.621 \\
\hline $\mathrm{EE}$ & $76.50^{\mathrm{a}}$ & $61.13^{b}$ & $46.67^{\mathrm{d}}$ & $49.61^{\mathrm{c}}$ & $51.74^{\mathrm{c}}$ & 0.756 \\
\hline $\mathrm{CP}$ & $68.56^{\mathrm{a}}$ & $65.78^{c}$ & $66.86^{\mathrm{b}}$ & $66.56^{\mathrm{b}}$ & $68.85^{\mathrm{a}}$ & 0.467 \\
\hline $\mathrm{CF}$ & $67.44^{\mathrm{a}}$ & $62.76^{\mathrm{d}}$ & $63.91^{\mathrm{c}}$ & $67.96^{\mathrm{a}}$ & $65.75^{\mathrm{b}}$ & 0.654 \\
\hline NFE & $72.02^{\mathrm{a}}$ & $59.49^{b}$ & $64.84^{\mathrm{b}}$ & $72.56^{\mathrm{a}}$ & $71.47^{\mathrm{a}}$ & 1.829 \\
\hline NDF & $56.69^{\mathrm{a}}$ & $45.16^{\mathrm{d}}$ & $48.82^{\mathrm{c}}$ & $49.05^{\mathrm{c}}$ & $52.18^{\mathrm{b}}$ & 0.725 \\
\hline $\mathrm{ADF}$ & $59.68^{\mathrm{a}}$ & $39.75^{\mathrm{c}}$ & $51.53^{\mathrm{b}}$ & $52.32^{\mathrm{b}}$ & $53.66^{\mathrm{b}}$ & 0.871 \\
\hline ADL & $60.79^{\mathrm{a}}$ & $41.57^{c}$ & $47.59^{\mathrm{b}}$ & $48.44^{\mathrm{b}}$ & $50.75^{\mathrm{b}}$ & 1.376 \\
\hline Cellulose & $59.72^{\mathrm{a}}$ & $45.81^{\mathrm{c}}$ & $52.99^{\mathrm{b}}$ & $54.86^{\mathrm{b}}$ & $54.89^{\mathrm{b}}$ & 1.085 \\
\hline Hemicellulose & $55.85^{\mathrm{a}}$ & $41.33^{\mathrm{d}}$ & $44.21^{\mathrm{cd}}$ & $49.23^{\mathrm{bc}}$ & $52.25^{\mathrm{ab}}$ & 1.849 \\
\hline \multirow{2}{*}{\multicolumn{7}{|c|}{ Nutritive value: }} \\
\hline & & & & & & \\
\hline $\mathrm{g} / \mathrm{h} / \mathrm{d}$ & $626.98^{b}$ & $522.78^{d}$ & $544.73^{c}$ & $647.10^{\mathrm{a}}$ & $623.40^{\mathrm{b}}$ & 13.193 \\
\hline $\mathrm{g} / \mathrm{kg} \mathrm{BW}$ & $12.85^{\mathrm{b}}$ & $10.63^{\mathrm{d}}$ & $11.11^{\mathrm{c}}$ & $13.22^{\mathrm{a}}$ & $12.74^{\mathrm{b}}$ & 0.308 \\
\hline$\%$ of DMI & $66.26^{\mathrm{a}}$ & $60.59^{d}$ & $57.68^{\mathrm{e}}$ & $64.92^{c}$ & $65.21^{\mathrm{b}}$ & 1.101 \\
\hline \multicolumn{7}{|l|}{ DCP } \\
\hline $\mathrm{g} / \mathrm{h} / \mathrm{d}$ & $85.21^{\mathrm{a}}$ & $59.76^{d}$ & $69.62^{c}$ & $78.12^{\mathrm{b}}$ & $81.82^{\mathrm{ab}}$ & 1.524 \\
\hline $\mathrm{g} / \mathrm{kg} \mathrm{BW}$ & $1.74^{\mathrm{a}}$ & $1.21^{\mathrm{d}}$ & $1.42^{\mathrm{c}}$ & $1.59^{\mathrm{b}}$ & $1.67^{\mathrm{ab}}$ & 0.042 \\
\hline$\%$ of DMI & $9.00^{\mathrm{a}}$ & $6.93^{\mathrm{e}}$ & $7.37^{\mathrm{d}}$ & $7.84^{\mathrm{c}}$ & $8.54^{\mathrm{b}}$ & 0.068 \\
\hline $\mathrm{ME}(\mathrm{Mcal} / \mathrm{kg} \mathrm{DM}) *$ & $22.69^{b}$ & $18.92^{\mathrm{d}}$ & $19.71^{\mathrm{c}}$ & $23.42^{\mathrm{a}}$ & $22.56^{\mathrm{b}}$ & 0.477 \\
\hline Feed costs L.E. $/ \mathrm{kg}$ & 4.750 & 3.910 & 4.07 & 4.15 & 4.23 & \\
\hline
\end{tabular}

Means with different letters with each row are significantly different $(P \leq 0.01)$.

$M E=$ Metabolic energy $=T D N$ g/head $\times 3.6$ (Church and Pond, 1982).

The price of one $\mathrm{kg}$ of CFM, BH, DPL and urea were 5.5, 4, 1.6 and 4 L.E., respectively.

It seems that $\mathrm{C}$ group had the best $(\mathrm{P} \leq 0.01)$ digestibility coefficients for all nutrients and fiber fractions compared to ureated and untreated rations, while $R 1$ had the lowest $(P \leq 0.01)$ digestibility coefficients. Ureated DPL increased $(\mathrm{P} \leq 0.01)$ the digestibility coefficients of DM, OM, EE, $\mathrm{CP}, \mathrm{CF}$, NFE, NDF, ADF, ADL, cellulose and hemicellulose compared to untreated group. The difference among 
$\mathrm{R} 4, \mathrm{R} 3, \mathrm{R} 2$ and $\mathrm{C}$ was not significant $(\mathrm{P} \leq 0.01)$ for digestibility coefficients of $\mathrm{DM}, \mathrm{OM}, \mathrm{CP}, \mathrm{CF}$ and NFE. This result indicated that rations contain ureated DPL considered good and had good digestibility coefficients, this means that partial or total replacement of hay by DPL had good benefits. Higher nutrients digestibility as a result of urea supplementation may be related to the microbial activities which solubilizing of carbohydrate esters of phenolic monomers in the cell wall (Khampa et al., 2009).

The data showed that urea treatments significantly $(\mathrm{P} \leq 0.01)$ increased TDN and DCP values $(\mathrm{g} / \mathrm{h} / \mathrm{d}$, $\mathrm{g} / \mathrm{kg} \mathrm{BW}$ and \% of DMI) compared to untreated group which was the lowest at all, R3 and R4 had the highest values then $\mathrm{R} 2$. Control group had the highest $(\mathrm{P} \leq 0.01)$ values of TDN and DCP compared with urea treatments. These results of TDN and DCP reflected the values of nutrient digestibility for rations which indicated that urea treatments were more efficient in nutrients digestibility compared with untreated DPL. Metabolic energy (Mcal/ $\mathrm{kg} \mathrm{DM}$ ) showed significant difference $(\mathrm{P} \leq 0.01)$ among rations, as that R3 followed by $\mathrm{C}$ and $\mathrm{R} 4$ then $\mathrm{R} 2$ showed the highest $(\mathrm{P} \leq 0.01)$ values, while $\mathrm{R} 1$ was the lowest $(\mathrm{P} \leq 0.01)$ value. Replacement of hay by $35 \%$ DPL decreased feed costs (L.E. $/ \mathrm{kg}$ ), as C group was higher compared to other groups, while R1 had the lowest feed costs.

Similar results were obtained by Aziz (2009) who demonstrated an increase in feed intake, digestibility coefficients of $\mathrm{DM}, \mathrm{OM}, \mathrm{EE}, \mathrm{CP}, \mathrm{CF}, \mathrm{NDF}, \mathrm{ADF}, \mathrm{ADL}$, cellulose and hemicellulose and an increase in TDN and DCP intake in sheep fed on olive trees by-products treated with $4 \%$ urea compared to control and untreated group. Also, Salman et al. (2011) showed that $3 \%$ urea treatment of agriculture by-products had increased DM, CP, EE and ash, while, decreased OM, CF and NFE. Okab et al. (2012) found that the inclusion of crop residue with $4 \%$ urea in the diet of sheep increased feed intake, digestibility coefficients of DM, OM and CP and increased ( $\mathrm{P}<0.05)$ TDN and DCP in comparison to untreated and control diets. Also, Khattab et al. (2013) reported that digestibility of DM, OM and CP have improved by urea supplementation in diets.

\section{Nitrogen balance:}

Data of Table (6) showed significant $(\mathrm{P} \leq 0.01)$ differences, whereas $\mathrm{C}$ ration increased $(\mathrm{P} \leq 0.01)$ nitrogen intake and digested nitrogen values $(\mathrm{g} / \mathrm{h} / \mathrm{d})$ more than $\mathrm{R} 4, \mathrm{R} 3, \mathrm{R} 2$ and $\mathrm{R} 1$, although ureated rations had highest DN (\% of NI) than $\mathrm{C}$, while $\mathrm{R} 1$ was the lowest one as $\mathrm{g} / \mathrm{h} / \mathrm{d}$. Total nitrogen excretion values $(\mathrm{g} / \mathrm{h} / \mathrm{d})$ were higher in $\mathrm{C}, \mathrm{R} 4, \mathrm{R} 3$ and $\mathrm{R} 2$ with no significant $(\mathrm{P} \leq 0.01)$ difference among them more than R1. While, R4 and R3 decreased $(\mathrm{P} \leq 0.01)$ total nitrogen excretion expressed relative to NI more than untreated ration. As control ration had the highest NI and DN, also it had the highest nitrogen balance $(\mathrm{g} / \mathrm{h} / \mathrm{d}, \%$ of $\mathrm{NI}$ and $\%$ of $\mathrm{DN})$ with highly significant $(\mathrm{P} \leq 0.01)$ differences with other rations. The three ureated rations increased $(\mathrm{P} \leq 0.01)$ nitrogen balance compared to untreated ration; R4 had the highest $(\mathrm{P} \leq 0.01)$ values followed by $\mathrm{R} 3$ then $\mathrm{R} 2$.

It seems that urea treatments for DPL increased nitrogen balance by 3.62, 2.99 and $1.61 \mathrm{~g} / \mathrm{h} / \mathrm{d}$ for R4, R3 and R2, respectively more than UDPL. The superiority in N balance by feeding urea treated DPL might be due to the higher improvement of its $\mathrm{OM}$ and $\mathrm{CP}$ digestibility or due to the higher utilization of urea $\mathrm{N}$ and thus lower total nitrogen excretion (R4 and R3) or might be related to higher improvement in rumen fermentation.

Similar results obtained by Mohamed et al. (1998) who indicated that N-balance of ureated rice straw (4\% urea) had significantly $(\mathrm{P}<0.05)$ the highest value than untreated and ammoniated rice straw. ElBadawi et al. (2003) found that dietary nitrogen utilization (\%N-balance of $\mathrm{N}$-intake) was obviously higher $(\mathrm{P}<0.05)$ with feed mixtures containing 50 and $75 \%$ SBP. Aziz (2009) demonstrated that the greatest nitrogen balance was produced in sheep fed on olive tree by-products treated with $4 \%$ urea compared to control group. Also, Okab et al. (2012) reported that total $\mathrm{N}$ excretion was increased $(\mathrm{P}<0.05)$ in untreated crop residues and control diets, while, $\mathrm{N}$ balance was greater $(\mathrm{P}<0.05)$ in diets treated with $4 \%$ urea compared to control and untreated diets.

\section{Microbial protein and rumen parameters:}

The data in Table (7) clarified that urea rations significantly $(\mathrm{P} \leq 0.01)$ increased microbial protein, true protein, ammonia nitrogen, non-protein nitrogen, total nitrogen and total volatile fatty acids concentrations than control and untreated rations. $\mathrm{R} 3$ had the highest $(\mathrm{P} \leq 0.01)$ values for all parameters concentrations followed by R4, while, R2 had the third class for all ruminal parameters concentrations, with no significant $(\mathrm{P} \leq 0.01)$ difference for the concentrations of NPN and TN among R3, R4 and R2. R1 had the lowest $(\mathrm{P} \leq 0.01)$ values of all parameters, while $\mathrm{C}$ was in the middle between ureated and unureated rations. 
Table (6): Nitrogen balance of sheep groups fed experimental rations.

\begin{tabular}{|c|c|c|c|c|c|c|}
\hline \multirow[b]{2}{*}{ Item } & \multicolumn{5}{|c|}{ Experimental ration } & \multirow[b]{2}{*}{$\pm \mathrm{SE}$} \\
\hline & $\mathrm{C}$ & $\mathrm{R} 1$ & $\mathrm{R} 2$ & R3 & $\mathrm{R} 4$ & \\
\hline \multicolumn{7}{|l|}{ Nitrogen intake $\mathrm{g} / \mathrm{h} / \mathrm{d}$} \\
\hline & $20.55^{\mathrm{a}}$ & $14.30^{\mathrm{d}}$ & $17.18^{c}$ & $18.77^{\mathrm{b}}$ & $19.00^{\mathrm{b}}$ & 0.418 \\
\hline \multicolumn{7}{|l|}{ Digested nitrogen } \\
\hline $\mathrm{g} / \mathrm{h} / \mathrm{d}$ & $18.88^{\mathrm{a}}$ & $13.54^{\mathrm{d}}$ & $16.21^{\mathrm{c}}$ & $17.77^{b}$ & $18.06^{\mathrm{a}}$ & 0.287 \\
\hline$\%$ of $\mathrm{N}$ intake & $92.22^{\mathrm{b}}$ & $94.70^{\mathrm{ab}}$ & $94.37^{\mathrm{ab}}$ & $94.65^{\mathrm{ab}}$ & $95.01^{\mathrm{a}}$ & 1.267 \\
\hline \multicolumn{7}{|l|}{ Fecal nitrogen } \\
\hline $\mathrm{g} / \mathrm{h} / \mathrm{d}$ & $6.25^{\mathrm{a}}$ & $4.73^{b}$ & $6.04^{\mathrm{a}}$ & $6.28^{\mathrm{a}}$ & $5.91^{\mathrm{a}}$ & 0.122 \\
\hline$\%$ of $\mathrm{N}$ intake & $30.49^{c}$ & $33.13^{b}$ & $35.16^{\mathrm{a}}$ & $33.43^{\mathrm{a}}$ & $31.145^{\mathrm{c}}$ & 0.552 \\
\hline \multicolumn{7}{|l|}{ Urinary nitrogen } \\
\hline $\mathrm{g} / \mathrm{h} / \mathrm{d}$ & $0.40^{\mathrm{ab}}$ & $0.42^{\mathrm{a}}$ & $0.38^{\mathrm{ab}}$ & $0.36^{\mathrm{bc}}$ & $0.33^{c}$ & 0.014 \\
\hline$\%$ of $\mathrm{N}$ intake & $1.95^{\mathrm{bc}}$ & $2.94^{\mathrm{a}}$ & $2.24^{\mathrm{b}}$ & $1.93^{\mathrm{bc}}$ & $1.75^{\mathrm{c}}$ & 0.107 \\
\hline \multicolumn{7}{|l|}{ Total $\mathrm{N}$ excretion } \\
\hline $\mathrm{g} / \mathrm{h} / \mathrm{d}$ & $6.65^{\mathrm{a}}$ & $5.16^{\mathrm{b}}$ & $6.42^{\mathrm{a}}$ & $6.64^{\mathrm{a}}$ & $6.24^{\mathrm{a}}$ & 0.124 \\
\hline$\%$ of $\mathrm{N}$ intake & $32.44^{\mathrm{c}}$ & $36.08^{\mathrm{ab}}$ & $37.41^{\mathrm{a}}$ & $35.36^{\mathrm{b}}$ & $32.89^{c}$ & 0.613 \\
\hline \multicolumn{7}{|l|}{ Nitrogen balance } \\
\hline $\mathrm{g} / \mathrm{h} / \mathrm{d}$ & $13.90^{\mathrm{a}}$ & $9.14^{\mathrm{d}}$ & $10.75^{\mathrm{c}}$ & $12.13^{\mathrm{b}}$ & $12.76^{\mathrm{b}}$ & 0.354 \\
\hline$\%$ of $\mathrm{N}$ intake & $67.55^{\mathrm{a}}$ & $63.92^{\mathrm{cb}}$ & $62.58^{c}$ & $64.63^{\mathrm{b}}$ & $67.10^{\mathrm{a}}$ & 0.613 \\
\hline$\%$ of digested $\mathrm{N}$ & $73.54^{\mathrm{a}}$ & $67.49^{b}$ & $66.31^{\mathrm{b}}$ & $68.28^{\mathrm{b}}$ & $70.62^{\mathrm{ab}}$ & 1.470 \\
\hline
\end{tabular}

Means with different letters with each row are significantly different $(P \leq 0.01)$.

Table (7): Microbial protein and ruminal parameters of sheep groups fed experimental rations.

\begin{tabular}{|c|c|c|c|c|c|c|c|c|}
\hline \multirow[b]{2}{*}{ Item } & \multirow[b]{2}{*}{ Time } & \multicolumn{6}{|c|}{ Experimental ration } & \multirow[t]{2}{*}{ Overall mean } \\
\hline & & $\mathrm{C}$ & R1 & $\mathrm{R} 2$ & R3 & $\mathrm{R} 4$ & $\pm \mathrm{SE}$ & \\
\hline $\begin{array}{l}\text { Microbial protein } \\
\text { mg/100mlRL }\end{array}$ & $\begin{array}{l}0 \\
4 \\
8\end{array}$ & $\begin{array}{c}65.15 \\
108.69 \\
87.00\end{array}$ & $\begin{array}{c}64.87 \\
108.34 \\
86.13\end{array}$ & $\begin{array}{c}69.78 \\
112.91 \\
93.20\end{array}$ & $\begin{array}{c}74.39 \\
122.63 \\
98.09\end{array}$ & $\begin{array}{c}73.42 \\
120.75 \\
97.57\end{array}$ & $\begin{array}{l}0.392 \\
0.392 \\
0.392\end{array}$ & $\begin{array}{c}69.52^{\mathrm{c}} \pm 0.175 \\
114.66^{\mathrm{a}} \pm 0.175 \\
92.40^{\mathrm{b}} \pm 0.175\end{array}$ \\
\hline $\begin{array}{l}\text { Overall mean } \\
\text { True protein } \\
\text { nitrogen mg/ } 100 \\
\text { ml R.L }\end{array}$ & $\begin{array}{l}0 \\
4 \\
8\end{array}$ & $\begin{array}{l}86.94^{\mathrm{d}} \\
34.09 \\
41.09 \\
37.00\end{array}$ & $\begin{array}{l}86.45^{\mathrm{d}} \\
32.10 \\
37.00 \\
33.51\end{array}$ & $\begin{array}{l}91.96^{\mathrm{c}} \\
43.59 \\
49.50 \\
45.92\end{array}$ & $\begin{array}{l}98.37^{\mathrm{a}} \\
46.48 \\
52.40 \\
47.76\end{array}$ & $\begin{array}{l}97.24^{\mathrm{b}} \\
45.11 \\
49.99 \\
47.23\end{array}$ & $\begin{array}{l}0.226 \\
1.017 \\
1.017 \\
1.017\end{array}$ & $\begin{array}{l}40.27^{\mathrm{c}} \pm 0.455 \\
45.99^{\mathrm{a}} \pm 0.455 \\
42.28^{\mathrm{b}} \pm 0.455\end{array}$ \\
\hline $\begin{array}{l}\text { Overall mean } \\
\text { Ammonia nitrogen } \\
\text { mg/ } 100 \mathrm{ml} \mathrm{R.L}\end{array}$ & $\begin{array}{l}0 \\
4 \\
8\end{array}$ & $\begin{array}{l}37.39^{c} \\
31.36 \\
37.03 \\
33.57\end{array}$ & $\begin{array}{l}34.20^{\mathrm{d}} \\
30.95 \\
35.05 \\
32.67\end{array}$ & $\begin{array}{c}46.33^{b} \\
34.08 \\
38.63 \\
35.52\end{array}$ & $\begin{array}{l}48.88^{\mathrm{a}} \\
39.37 \\
45.94 \\
42.28\end{array}$ & $\begin{array}{c}47.44^{\mathrm{ab}} \\
37.85 \\
44.42 \\
40.38\end{array}$ & $\begin{array}{l}0.587 \\
0.432 \\
0.432 \\
0.432\end{array}$ & $\begin{array}{l}34.72^{\mathrm{c}} \pm 0.193 \\
40.21^{\mathrm{a}} \pm 0.193 \\
36.88^{\mathrm{b}} \pm 0.193\end{array}$ \\
\hline $\begin{array}{l}\text { Overall mean } \\
\text { NPN mg/100 ml } \\
\text { R.L }\end{array}$ & $\begin{array}{l}0 \\
4 \\
8\end{array}$ & $\begin{array}{l}33.99^{d} \\
60.71 \\
79.05 \\
73.06\end{array}$ & $\begin{array}{l}32.89^{\mathrm{e}} \\
58.67 \\
77.99 \\
72.89\end{array}$ & $\begin{array}{l}36.08^{c} \\
66.18 \\
79.20 \\
72.85\end{array}$ & $\begin{array}{l}42.53^{\mathrm{a}} \\
68.11 \\
82.28 \\
75.75\end{array}$ & $\begin{array}{l}40.88^{b} \\
67.07 \\
81.54 \\
74.16\end{array}$ & $\begin{array}{l}0.249 \\
1.569 \\
1.569 \\
1.569\end{array}$ & $\begin{array}{l}64.15^{\mathrm{c}} \pm 0.701 \\
80.01^{\mathrm{a}} \pm 0.701 \\
73.74^{\mathrm{b}} \pm 0.701\end{array}$ \\
\hline $\begin{array}{l}\text { Overall mean } \\
\text { Total nitrogen } \\
\text { mg/100 ml R.L }\end{array}$ & $\begin{array}{l}0 \\
4 \\
8\end{array}$ & $\begin{array}{c}70.94^{\mathrm{bc}} \\
94.80 \\
120.14 \\
110.06\end{array}$ & $\begin{array}{c}69.85^{\mathrm{c}} \\
90.77 \\
114.99 \\
106.40\end{array}$ & $\begin{array}{l}72.74^{\mathrm{ab}} \\
109.77 \\
128.70 \\
118.77\end{array}$ & $\begin{array}{l}75.38^{\mathrm{a}} \\
114.60 \\
134.69 \\
123.52\end{array}$ & $\begin{array}{l}74.26^{\mathrm{a}} \\
112.18 \\
131.53 \\
121.40\end{array}$ & $\begin{array}{l}0.905 \\
1.673 \\
1.673 \\
1.673\end{array}$ & $\begin{array}{l}104.42^{\mathrm{c}} \pm 0.748 \\
126.01^{\mathrm{a}} \pm 0.748 \\
116.03^{\mathrm{b}} \pm 0.748\end{array}$ \\
\hline $\begin{array}{l}\text { Overall mean } \\
\text { TVFA's ml } \\
\text { equiv/100 ml R.L }\end{array}$ & $\begin{array}{l}0 \\
4 \\
8\end{array}$ & $\begin{array}{c}108.33^{c} \\
7.07 \\
8.89 \\
8.11\end{array}$ & $\begin{array}{c}104.05^{\mathrm{d}} \\
6.71 \\
8.71 \\
7.70\end{array}$ & $\begin{array}{c}119.08^{\mathrm{b}} \\
7.35 \\
10.73 \\
9.15\end{array}$ & $\begin{array}{c}124.27^{\mathrm{a}} \\
7.55 \\
11.85 \\
10.01\end{array}$ & $\begin{array}{c}121.70^{\mathrm{ab}} \\
7.70 \\
11.28 \\
9.32\end{array}$ & $\begin{array}{l}0.965 \\
0.154 \\
0.154 \\
0.154\end{array}$ & $\begin{array}{c}7.27^{\mathrm{c}} \pm 0.069 \\
10.29^{\mathrm{a}} \pm 0.069 \\
8.86^{\mathrm{b}} \pm 0.069\end{array}$ \\
\hline $\begin{array}{l}\text { Overall mean } \\
\mathrm{pH}\end{array}$ & $\begin{array}{l}0 \\
4 \\
8\end{array}$ & $\begin{array}{l}8.02^{\mathrm{d}} \\
7.39 \\
6.41 \\
6.61\end{array}$ & $\begin{array}{l}7.70^{\mathrm{e}} \\
6.86 \\
6.04 \\
6.46\end{array}$ & $\begin{array}{l}9.08^{\mathrm{c}} \\
6.48 \\
5.86 \\
5.99\end{array}$ & $\begin{array}{l}9.80^{\mathrm{a}} \\
6.51 \\
5.96 \\
6.15\end{array}$ & $\begin{array}{l}9.43^{\mathrm{b}} \\
6.76 \\
5.96 \\
6.26\end{array}$ & $\begin{array}{l}0.089 \\
0.095 \\
0.095 \\
0.095\end{array}$ & $\begin{array}{l}6.80^{\mathrm{a}} \pm 0.042 \\
6.05^{\mathrm{c}} \pm 0.042 \\
6.29^{\mathrm{b}} \pm 0.042\end{array}$ \\
\hline Overall mean & & $6.80^{\mathrm{a}}$ & $6.45^{\mathrm{b}}$ & $6.11^{\mathrm{d}}$ & $6.21^{\mathrm{cd}}$ & $6.33^{\mathrm{bc}}$ & 0.055 & \\
\hline
\end{tabular}


The overall means at different sampling times showed that the lowest $(\mathrm{P} \leq 0.01)$ values were at zero $\mathrm{hr}$ per-feeding then showed a significant increase $(\mathrm{P} \leq 0.01)$ to reach the highest $(\mathrm{P} \leq 0.01)$ values after 4 hrs post-feeding then showed decrease $(\mathrm{P} \leq 0.01)$ with progressed time of feeding at $8 \mathrm{hrs}$ post-feeding. It is clear that the levels of $6 \%$ and $8 \%$ urea enhanced all rumen parameters concentrations more than the level of $4 \%$ urea; this is may be due to the highest digestibility of $\mathrm{CP}$ and the highest nitrogen balance.

Ruminal $\mathrm{pH}$ concentrations showed that urea rations decreased $(\mathrm{P} \leq 0.01)$ ruminal $\mathrm{pH}$ values more than $\mathrm{C}$ and $\mathrm{R} 1$, the lowest $(\mathrm{P} \leq 0.01)$ ruminal $\mathrm{pH}$ was for $\mathrm{R} 2$ followed by $\mathrm{R} 3$ then $\mathrm{R} 4$, while, $\mathrm{C}$ had the highest $(\mathrm{P} \leq 0.01)$ value followed by $\mathrm{R} 1$. The overall means at the different sampling times was at the opposite of other rumen parameters as it showed that the highest value was at zero time pre-feeding then it showed a significant decrease $(\mathrm{P} \leq 0.01)$ after $4 \mathrm{hrs}$ post-feeding then increased with progressed time of feeding.

The improvement in rumen parameters by urea treatments may be due to the improvement in microbial population in the rumen which plays an important role in rumen fermentation. Also, there was a good efficiency in ruminal protein synthesis when a NPN source was in feeds containing rapidly fermentable carbohydrates (Lanza et al., 2001).

The present results are supported by the results of Gado et al. (2007) who reported that the ruminal ammonia nitrogen levels were higher in sheep fed ureated yellow corn or barley grains at early hours after feeding than in those fed diets containing true protein (controls). Aziz (2009) demonstrated a decrease in ruminal $\mathrm{pH}$, and an increase in ruminal TVFA's, total nitrogen, true protein, non-protein nitrogen and ammonia nitrogen concentrations in sheep fed on olive tree by-products treated with $4 \%$ urea compared to control and untreated group. Khattab et al. (2013) reported that urea supplementation in diets improved microbial N production. Phillip et al. (2014) reported that the highest values of ruminal ammonia nitrogen were observed with sheep fed roughage treated with urea, also urea treatment increased TVFA's and microbial protein compared to control.

\section{Ruminal ciliate protozoa:}

Data of Table (8) indicated that seven subspecies for seven genus of ruminal protozoa were identified in the ruminal fluid of the experimental sheep groups, which were Polyolastron spp., Diplodinum spp., Ophryoscolox spp., Dasytrachia spp., Isotrachia spp., Epidinium spp. and Entodinum spp. A significant increase $(\mathrm{P} \leq 0.01)$ was found in differential and total numbers of ruminal ciliate protozoa $\left(\times 10^{4} \mathrm{cell} / \mathrm{ml}\right.$ rumen liquor) with $\mathrm{R} 2, \mathrm{R} 3$ and $\mathrm{R} 4$ more than $\mathrm{R} 1$ which had the lowest $(\mathrm{P} \leq 0.01)$ numbers of all species except for Diplodinum spp. R3 had the highest $(\mathrm{P} \leq 0.01)$ density followed by $\mathrm{R} 4$ with no significant $(\mathrm{P} \leq 0.01)$ difference between them for numbers of Isotrachia, Epidinium, Entodinum spps, while R2 was the third one except it had the lowest numbers of Ophryoscolox, Dasytrachia, Entodinum spps and TC with no significant $(\mathrm{P} \leq 0.01)$ difference with $\mathrm{R} 1$.

There was non-significant $(\mathrm{P} \leq 0.01)$ difference among $\mathrm{C}$ and ureated rations for numbers of Polyolastron, Dasytrachia, Isotrachia, Epidinium, Entodinum spps and TC, this indicated that rations contained ureated DPL were efficient as the control ration. Entodinum spp. was the highest among all species. This result is in agreement with those of Ivan et al. (2000) who reported that Entodinum was the most detrimental of ciliate protozoa species. Different sampling times indicated lower values at zero $\mathrm{hr}$ pre-feeding then increased $(\mathrm{P} \leq 0.01)$ at $4 \mathrm{hrs}$ then decreased at $8 \mathrm{hrs}$ post-feeding. In the present study, the increasing of protozoa number after $4 \mathrm{hr}$ post-feeding may be related to that ruminal $\mathrm{pH}$ was higher than 6 .

Similar results were obtained by Bhatia et al. (1992) who indicated that total protozoa count decreased $2 \mathrm{hrs}$ after feeding and increased significantly $6 \mathrm{hrs}$ post-feeding. Aziz (2009) found that feeding sheep on olive tree by-products treated with $4 \%$ urea increased total ruminal protozoa count and the deferential number of species compared to control and untreated group. Phillip et al. (2014) found that total fungal count was significantly increased when roughage treated with urea compared with control. Aboamer et al. (2018) found that urea treatments at level of 2, 4 and $6 \%$ increased all ruminal protozoa species and its total count in ruminal fluid of experimental sheep more than untreated and control groups.

\section{Blood parameters:}

Serum urea values $\mathrm{mg} / \mathrm{dl}$ (Table 9) were significantly increased $(\mathrm{P} \leq 0.01)$ with ureated rations more than $\mathrm{C}$ and R1. The highest value was for R4 followed by R3 then R2, while the lowest value was for R1 and $\mathrm{C}$ with no significant $(\mathrm{P} \leq 0.01)$ difference between them. The increase in blood urea in ureated DPL rations might be due to partial increase in ruminal ammonia for ureated DPL rations. The difference among the five rations was not significant for blood ALT concentration as they almost the same value, while R1 increased $(\mathrm{P} \leq 0.01)$ blood AST concentration more than other rations. 
Table (8): Ruminal ciliate protozoa count $\left(\mathrm{x}^{4} 0^{4}\right.$ cell $/ \mathrm{ml}$ rumen liquor) of sheep groups fed experimental rations.

\begin{tabular}{|c|c|c|c|c|c|c|c|c|}
\hline \multirow[b]{2}{*}{ Items } & \multirow[b]{2}{*}{ Time } & \multicolumn{6}{|c|}{ Experimental rations } & \multirow[t]{2}{*}{ Overall mean } \\
\hline & & $\mathrm{C}$ & R1 & R2 & R3 & $\mathrm{R} 4$ & $\pm \mathrm{SE}$ & \\
\hline \multirow{3}{*}{$\begin{array}{l}\text { Polyolastron } \\
\text { spp. }\end{array}$} & 0 & 0.330 & 0.295 & 0.322 & 0.350 & 0.336 & 0.006 & $0.326^{c} \pm 0.002$ \\
\hline & 4 & 0.372 & 0.387 & 0.391 & 0.451 & 0.420 & 0.006 & $0.404^{\mathrm{a}} \pm 0.002$ \\
\hline & 8 & 0.359 & 0.332 & 0.360 & 0.401 & 0.385 & 0.006 & $0.367^{\mathrm{b}} \pm 0.002$ \\
\hline \multirow{4}{*}{$\begin{array}{l}\text { Overall mean } \\
\text { Diplodinum } \\
\text { spp. }\end{array}$} & & $0.354^{c}$ & $0.338^{\mathrm{d}}$ & $0.357^{\mathrm{c}}$ & $0.400^{\mathrm{a}}$ & $0.380^{\mathrm{b}}$ & 0.003 & \\
\hline & 0 & 0.128 & 0.127 & 0.129 & 0.152 & 0.145 & 0.005 & $0.136^{\mathrm{c}} \pm 0.002$ \\
\hline & 4 & 0.215 & 0.215 & 0.208 & 0.253 & 0.222 & 0.005 & $0.222^{\mathrm{a}} \pm 0.002$ \\
\hline & 8 & 0.167 & 0.332 & 0.163 & 0.201 & 0.182 & 0.005 & $0.209^{b} \pm 0.002$ \\
\hline \multirow{4}{*}{$\begin{array}{l}\text { Overall mean } \\
\text { Ophryoscolox } \\
\text { spp }\end{array}$} & & $0.170^{\mathrm{d}}$ & $0.225^{\mathrm{a}}$ & $0.166^{\mathrm{d}}$ & $0.202^{\mathrm{b}}$ & $0.183^{c}$ & 0.003 & \\
\hline & 0 & 0.172 & 0.160 & 0.165 & 0.183 & 0.171 & 0.003 & $0.170^{c} \pm 0.001$ \\
\hline & 4 & 0.245 & 0.238 & 0.225 & 0.264 & 0.255 & 0.003 & $0.245^{\mathrm{a}} \pm 0.001$ \\
\hline & 8 & 0.205 & 0.196 & 0.196 & 0.226 & 0.213 & 0.003 & $0.207^{\mathrm{b}} \pm 0.001$ \\
\hline \multirow{4}{*}{$\begin{array}{l}\text { Overall mean } \\
\text { Dasytrachia } \\
\text { spp. }\end{array}$} & & $0.207^{\mathrm{c}}$ & $0.198^{\mathrm{d}}$ & $0.195^{\mathrm{d}}$ & $0.224^{\mathrm{a}}$ & $0.213^{\mathrm{b}}$ & 0.001 & \\
\hline & 0 & 0.402 & 0.394 & 0.390 & 0.463 & 0.409 & 0.009 & $0.412^{\mathrm{c}} \pm 0.004$ \\
\hline & 4 & 0.491 & 0.491 & 0.481 & 0.573 & 0.505 & 0.009 & $0.508^{\mathrm{a}} \pm 0.004$ \\
\hline & 8 & 0.404 & 0.423 & 0.408 & 0.457 & 0.430 & 0.009 & $0.425^{\mathrm{b}} \pm 0.004$ \\
\hline \multirow{4}{*}{$\begin{array}{l}\text { Overall mean } \\
\text { Isotrachia spp. }\end{array}$} & & $0.432^{\mathrm{bc}}$ & $0.436^{\mathrm{bc}}$ & $0.426^{\mathrm{c}}$ & $0.498^{\mathrm{a}}$ & $0.448^{b}$ & 0.005 & \\
\hline & 0 & 0.207 & 0.182 & 0.186 & 0.227 & 0.200 & 0.004 & $0.200^{c} \pm 0.002$ \\
\hline & 4 & 0.289 & 0.215 & 0.256 & 0.307 & 0.279 & 0.004 & $0.269^{\mathrm{a}} \pm 0.002$ \\
\hline & 8 & 0.239 & 0.185 & 0.216 & 0.247 & 0.234 & 0.004 & $0.224^{b} \pm 0.002$ \\
\hline \multirow{4}{*}{$\begin{array}{l}\text { Overall mean } \\
\text { Epidinium spp }\end{array}$} & & $0.245^{\mathrm{a}}$ & $0.194^{\mathrm{d}}$ & $0.219^{c}$ & $0.260^{\mathrm{a}}$ & $0.238^{\mathrm{a}}$ & 0.002 & \\
\hline & 0 & 0.171 & 0.166 & 0.156 & 0.174 & 0.172 & 0.017 & $0.168^{c} \pm 0.007$ \\
\hline & 4 & 0.214 & 0.214 & 0.214 & 0.278 & 0.231 & 0.017 & $0.230^{\mathrm{a}} \pm 0.007$ \\
\hline & 8 & 0.201 & 0.196 & 0.185 & 0.221 & 0.200 & 0.017 & $0.202^{\mathrm{b}} \pm 0.007$ \\
\hline \multirow{4}{*}{$\begin{array}{l}\text { Overall mean } \\
\text { Entodinum } \\
\text { spp. }\end{array}$} & & $0.195^{\mathrm{ab}}$ & $0.192^{c}$ & $0.185^{\mathrm{b}}$ & $0.224^{\mathrm{a}}$ & $0.201^{\mathrm{ab}}$ & 0.010 & \\
\hline & 0 & 5.109 & 4.939 & 4.786 & 5.205 & 5.023 & 0.086 & $5.012^{\mathrm{c}} \pm 0.038$ \\
\hline & 4 & 5.276 & 5.247 & 5.190 & 5.472 & 5.367 & 0.086 & $5.310^{\mathrm{a}} \pm 0.038$ \\
\hline & 8 & 5.283 & 5.132 & 4.992 & 5.325 & 5.230 & 0.086 & $5.192^{\mathrm{b}} \pm 0.038$ \\
\hline \multirow{4}{*}{$\begin{array}{l}\text { Overall mean } \\
\text { Total protozoa } \\
\text { count }\end{array}$} & & $5.222^{\mathrm{ab}}$ & $5.106^{\mathrm{b}}$ & $4.989^{c}$ & $5.334^{\mathrm{a}}$ & $5.206^{\mathrm{ab}}$ & 0.049 & \\
\hline & 0 & 6.520 & 6.265 & 6.136 & 6.754 & 6.457 & 0.083 & $6.426^{\mathrm{c}} \pm 0.037$ \\
\hline & 4 & 7.105 & 7.009 & 6.968 & 7.599 & 7.281 & 0.083 & $7.192^{\mathrm{a}} \pm 0.037$ \\
\hline & 8 & 6.860 & 6.798 & 6.521 & 7.081 & 6.877 & 0.083 & $6.827^{\mathrm{b}} \pm 0.037$ \\
\hline \multicolumn{2}{|l|}{ Overall mean } & $6.828^{\mathrm{b}}$ & $6.690^{c}$ & $6.542^{\mathrm{c}}$ & $7.144^{\mathrm{a}}$ & $6.872^{\mathrm{b}}$ & 0.048 & \\
\hline
\end{tabular}

Means with different letters with each row are significantly different $(P \leq 0.01)$.

The highest $(\mathrm{P} \leq 0.01)$ values of serum total protein and albumin values $(\mathrm{g} / \mathrm{dl})$ were for $\mathrm{R} 3$ followed by R4 then R2 with no significant $(\mathrm{P} \leq 0.01)$ difference among $\mathrm{R} 3, \mathrm{R} 4, \mathrm{R} 2$ and $\mathrm{C}$, while the lowest $(\mathrm{P} \leq 0.01)$ values were for R1. Control was the first for globulin values $(\mathrm{g} / \mathrm{dl})$ followed by $\mathrm{R} 1$ then $\mathrm{R} 2$ with no significant $(\mathrm{P} \leq 0.01)$ difference, while the lowest $(\mathrm{P} \leq 0.01)$ values were for $\mathrm{R} 4$ and $\mathrm{R} 3$. All blood parameters were higher $(\mathrm{P} \leq 0.01) 4 \mathrm{~h}$ post-feeding than pre-feeding values. These results indicated that feeding rations contained ureated and untreated DPL did not cause any lesions in liver and kidney functions of sheep.

The present results are supported by the results of Gado et al. (2007) who reported that total protein, albumin, globulin and $\mathrm{A} / \mathrm{G}$ ratio concentrations for sheep fed ureated yellow corn or ureated barley grains (4\% urea) were higher comparing with control and untreated groups. Although, serum urea concentrations were higher in treated groups. While, there was no differences in GPT and GOT values among groups. Also, Aziz (2009) reported that serum total proteins, albumin and globulin were higher in sheep fed on olive tree by-products treated with $4 \%$ urea compared to control and untreated group, while serum urea GPT and GOT values were decreased. Phillip et al. (2014) found that urea treatment significantly increased blood plasma urea, while there was insignificant difference for total protein, albumin, globulin, GOT and GPT when roughage treated with urea compared with control. Aboamer et al. (2018) indicated that feeding crop residue treated with urea $(2,4$ and $6 \%)$ increased serum total protein, albumin and globulin for sheep, while serum urea and AST concentrations decreased in treated groups. 
Table (9): Blood parameters of sheep groups fed experimental rations.

\begin{tabular}{|c|c|c|c|c|c|c|c|c|}
\hline \multirow[b]{2}{*}{ Item } & \multirow[b]{2}{*}{ Time } & \multicolumn{6}{|c|}{ Experimental ration } & \multirow[t]{2}{*}{ Overall mean } \\
\hline & & $\mathrm{C}$ & $\mathrm{R} 1$ & $\mathrm{R} 2$ & R3 & $\mathrm{R} 4$ & $\pm \mathrm{SE}$ & \\
\hline \multirow[t]{2}{*}{ Urea $\mathrm{mg} / \mathrm{dl}$} & 0 & 21.59 & 21.24 & 28.11 & 28.70 & 30.59 & 0.633 & $26.05^{b} \pm 0.283$ \\
\hline & 4 & 24.23 & 24.11 & 34.85 & 35.87 & 37.69 & 0.633 & $31.35^{\mathrm{a}} \pm 0.283$ \\
\hline \multirow{3}{*}{$\begin{array}{l}\text { Overall mean } \\
\text { ALT U/L }\end{array}$} & & $22.91^{\mathrm{d}}$ & $22.68^{\mathrm{d}}$ & $31.48^{\mathrm{c}}$ & $32.29^{\mathrm{b}}$ & $34.14^{\mathrm{a}}$ & 0.447 & \\
\hline & 0 & 13.66 & 13.61 & 13.54 & 13.74 & 13.53 & 0.145 & $13.61^{\mathrm{b}} \pm 0.065$ \\
\hline & 4 & 15.15 & 15.67 & 15.14 & 15.81 & 15.23 & 0.145 & $15.40^{\mathrm{a}} \pm 0.065$ \\
\hline \multirow{3}{*}{$\begin{array}{l}\text { Overall mean } \\
\text { AST U/L }\end{array}$} & & 14.41 & 14.64 & 14.34 & 14.77 & 14.38 & 0.102 & \\
\hline & 0 & 22.37 & 23.09 & 22.19 & 21.79 & 20.36 & 0.595 & $21.96^{\mathrm{b}} \pm 0.266$ \\
\hline & 4 & 23.43 & 25.71 & 23.19 & 23.41 & 22.08 & 0.595 & $23.56^{\mathrm{a}} \pm 0.266$ \\
\hline \multirow{3}{*}{$\begin{array}{l}\text { Overall mean } \\
\text { Total proteins g/dl }\end{array}$} & & $22.90^{\mathrm{b}}$ & $24.40^{\mathrm{a}}$ & $22.69^{b}$ & $22.60^{\mathrm{b}}$ & $21.22^{\mathrm{b}}$ & 0.421 & \\
\hline & 0 & 7.96 & 7.13 & 7.34 & 8.19 & 7.91 & 0.088 & $7.71^{b} \pm 0.039$ \\
\hline & 4 & 8.60 & 7.90 & 8.27 & 9.34 & 8.60 & 0.088 & $8.54^{\mathrm{a}} \pm 0.039$ \\
\hline \multirow{3}{*}{$\begin{array}{l}\text { Overall mean } \\
\text { Albumin } \mathrm{g} / \mathrm{dl}\end{array}$} & & $8.28^{b}$ & $7.52^{d}$ & $7.80^{c}$ & $8.77^{\mathrm{a}}$ & $8.25^{b}$ & 0.062 & \\
\hline & 0 & 4.062 & 3.14 & 3.66 & 4.82 & 4.65 & 0.106 & $4.07^{b} \pm 0.047$ \\
\hline & 4 & 4.35 & 3.79 & 4.12 & 5.29 & 5.18 & 0.106 & $4.54^{\mathrm{a}} \pm 0.047$ \\
\hline \multirow{3}{*}{$\begin{array}{l}\text { Overall mean } \\
\text { Globulin g/dl }\end{array}$} & & $4.20^{\mathrm{b}}$ & $3.46^{\mathrm{d}}$ & $3.89^{c}$ & $5.05^{\mathrm{a}}$ & $4.91^{\mathrm{a}}$ & 0.075 & \\
\hline & 0 & 3.90 & 3.99 & 3.68 & 3.37 & 3.26 & 0.107 & $3.64^{b} \pm 0.048$ \\
\hline & 4 & 4.24 & 4.11 & 4.14 & 4.05 & 3.42 & 0.107 & $3.99^{\mathrm{a}} \pm 0.048$ \\
\hline Overall mean & & $4.076^{\mathrm{a}}$ & $4.05^{\mathrm{a}}$ & $3.91^{\mathrm{ab}}$ & $3.71^{\mathrm{b}}$ & $3.34^{\mathrm{c}}$ & 0.076 & \\
\hline
\end{tabular}

\section{CONCLUSION}

Urea treatments for date palm leaves improved chemical composition and fiber fraction. Feeding rations contained date palm leaves increased all nutrients digestibility coefficients and improved nitrogen balance, which reflected on microbial protein and rumen fermentations. All these improvements suggest the possibility of replacement of date palm leaves supplemented with urea or not by a part of hay in sheep rations.

\section{REFERENCES}

Aboamer, A.A.; Aziz, Hend A.; H. H.Azzaz; Hoda Alzahar and H.A. Murad (2018). Impact of ureatreated olive trees by-products on Barki ewe's nutrients digestibility and milk productivity. Egyptian Journal of Nutrition and Feeds, 21 (3): 611-621.

Abou-Hussein, E.R.N.; A.K. Abou-Raya; A. S. Shalaby and O.A.L. Salem (1982). National and physiological studies with short time alkali treated roughage. 1. Maize stalks as affected by different methods of treatment. Six Inter. Conf. Anim. And Prod. Zagazig Univ.

AOAC (1995). Association of Official Analytical Chemists. Official methods of analysis. $15^{\text {th }}$ ed. Arlongton, Virginia, USA.

Armstrong, W.D. and C.W. Carr (1964). Physiological Chemistry, 3rd Ed. Laboratory Directions Bures Publishing Co. Minneapolis, Minnesota, USA.

Aziz, Hend A. (2009). Effect of feeding olive tree pruning by-products in Sinai on sheep performance. Ph. D. thesis, Fac. of Agric., Ain Shams Univ.

Bahman, A.M.; J.H.Topps and J.A. Rooke (1997). Use of date palm leaves in high concentratate diets for lactating Frisian and Holstein cows. J. Arid Environ., 35: 141-146.

Bhatia, J.S; A.K. Ghosal; W.R.Allen; A. J. Higgins; I.G. Mayhew; D.H. Snow and J.F. Wade (1992). Studies on fermentation in the camel (Camelus dromedaries). Proc. of first inter. Camel Conf., Dubai, 2-6 th Feb., 1992, 271-274. 
Chesson, A.; A. H. Gordon and J. A. Loxnax (1983). Substituent group linked by alkali-labile bonds to arabinose and xylose rowdies of digestion by rumen microorganisms. J./ Saifd. Agric. 93 Pp: 1330.

Church, D.C. and W.G.Pond (1982). Basic animal nutrition and feeding, 2nd ed. Johnwiley and sons, New York, U.S.A.

Dehority, B. A. (1993). Laboratory Manual for Classification and Morphology of Rumen Ciliate Protozoa. CRC. Press Inc., Florida.

Doumas, Wabson and H. Biggs (1971). Albumin standards and measurement of serum with bromocresol green. Din. Chern. Acta. 31: 87.

Duncan, D.B. (1955). Multiple range and multiple F-test. Biometrics. 11:1-42.

El-Badawi, A.Y.; H.M. Yacout and H.E.M. Kamel (2003). Effect of replacing corn with sugar beet pulp on ruminal degradation kinetics and utilization efficiency of rations by growing sheep. Egyptian Journal of Nutrition and Feeds, 6, 1349-1363.

Fouad, R. T; T. A. Deraz and A. A. Ismail (1998). Biological versus urea treatment of roughage for sheep. J. Agic. Sci., Mansoura Univ., 23 (1): 103-116.

Gado,H.; H.M. Metwally; M.F. El-Sayes and F.A. El-Sayed (2007). Effect of ureated energy sources on performance of crossbred lambs. Egyptian J. Nutrition and Feeds, 10 (2)(Special Issue): 693-708.

Ivan, M.; L. Neill; R. Forster; R. Alimon; T.L.M. Rode and T. Entz (2000). Effects of Isotricha, Dasytricha, Entodinum, and total Fauna on ruminal fermentation and duodenal flow in wethers fed different diets. J. Dairy Sci. 83: 776-787.

Khampa, S.; P.chaowwarat; R.Singhalert; R.Pilajun and M. Wanapat (2009). Supplementation of yeast fermented Cassava chip as a replacement concentrate on rumen fermentation efficiency amd digestibility of nutrients in heifer. J.Anim. and Vet. Advances. 8(6):1091-1095.

Khattab, I.M; A.Z.M.Salem; A.M. Abdel-wahed and K.Z. Kewan (2013). Effects of urea supplementation on nutrient digestibility, nitrogen utilization and rumen fermentation in sheep fed diets containing dates. Livest. Sci. 155, 223-229.

Koening, K. M. and K.A. Beauchemin (2005). Barley protein supplemented corn-based dioets for feedlot cattle evaluated using the NRC and CNCPS beef models. Can. J. Anim. Sci. 85: 377-388.

Lanza, M.; A. Priolo; L. Biondi; M. Bella and H.B. Salem (2001). Replacement of cereal grains by orange pulp and carob pulp in soya bean-based diets fed to lambs: effects on growth performance and meat quality. Animal Research, 50 (1): 21-30.

Mohamed, A.H.; T.A.A. Deraz and A.A. Abdel Aziz (1998). Effect of chemical treatment of straw with different methods on intake, digestibility and lambs performance. J. Agri. Sci. Mansoura Univ., 23 (12): 5297-5306.

Naqadi. S.A.; H.E. El-Sobhy and Y.A.O. Al-Maroai (2006). Palm leaves treated with urea as a dietary ingredient in rams diets and its effects on carcass characteristics. Egyptian J. Nutrition and Feeds, 9(2): 315-333.

Norris, K.H. (1976). Predicting forage quality by infrared reflectance spectroscopy. J.Anim. Sci., 43:889.

Ogimoto, K. and Imai, S. (1981). Atlas of Rumen Microbial-Ogy. Japan Scientific Societies Press, Tokyo.

Okab, B .A; A. M. Ayoub; S. M. Emad; K. A. Abdoun; A. A. Al-Haidary; A.A. Koriem and A.A. Hassan (2012). Improvement of growth and nitrogen utilization in sheep using sugar beet pulp treated with Trichoderma reesei or urea. Trop. Anim. Health Prod. 10:1-7.

Patton, C. J. and S.R. Crouch (1977). Spectrophotomentic and kinetics investigation of the Berthelot reaction for the determination of ammonia. Anal. Chem., 49: 464-469.

Phillip, Y.L.; A.A.Mahrous; A.A.Khir and Safa N. Abdel-Azeem (2014). Productive performance of small ruminants fed pruning fruits trees by-products. 1- Effect of treated pruning grape trees byproducts on growing Ossimi lambs. Egyptian J. Nutrition and Feeds 17 (3): 409-421.

Salman, F.M.; R. Satama; A.E. khattab; S.M. Soliman; and Y.A. El- Nomeary (2011). Chemical, biological and biochemical treatments to improve the nutritive values of sugarcane bagasse (SCB): 
1-Chemical composition, scanning electron microscopy, in vitro evaluation, nutrients digestibility and nitrogen utilization of untreated or treated SCB. Life Science Journal, 8, 351- 363.

SAS (2004). SAS/STAT 9.1.3 User's Guide: Statistical Analysis Systems Institute Inc., Release 8.1, Cary, NC., USA.

Shoukry, M.M. (1992). Effect of urea treatment on chemical composition, in vitro dry matter disappearance and degradability of dry matter and cell wall constituents of some poor quality roughages. Annals of Agric. Moshtohor, 30:677.

Shoukry, M.M.; H.M. Ali; M.A. El-Ashry, M.A. and F.M. Salman (1992). Effect of urea treatment and ensiling period on the chemical composition, nitrogen fixation and nutritive value of some poor quality roughages. Zagazig J. Agric. Res., 19:1795.

Van Soest, P. J. (1994). The Nutritional Ecology of the Ruminant, $2^{\text {nd }}$ edition. Cornell University Press. Ithaca, N Y., 476p.

Warner, A.C.J. (1964). Production of volatile fatty acids in the rumen methods of measurments. Nutr. Abst. \& Rev.34:339.

Wikison, J.H.; D.N. Barn; D.W. Moss and P.G. Walker (1972). Standardization of clinical enzyme assays. A reference method for aspartate and alanine transaminases. J. Clin. Pathol., 25:940.

\section{تحسين القيمة الغذائية لسعف النخيل باستخدام معاملة اليوريا وتأثيره على تغذية المجترات الصغيرة}

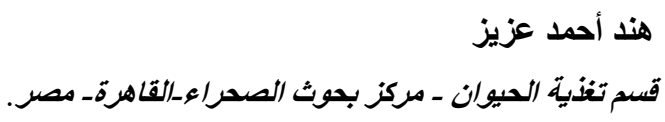

الهدف من هذه الدراسة هو تقييم تأثير إحلال دريس البرسيم فى العلائق بسعف النخيل غير المعامل أو المعامل باليورياو در اسة تأثير

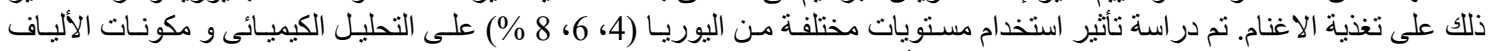

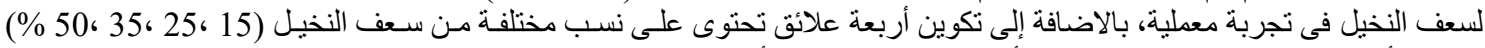

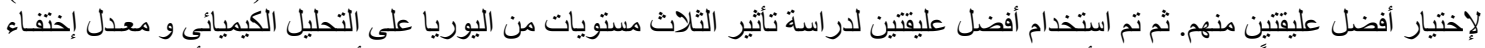

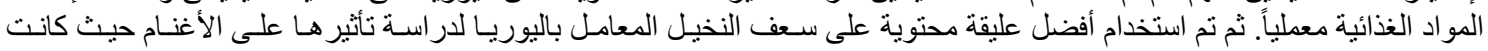

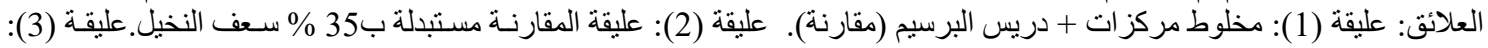

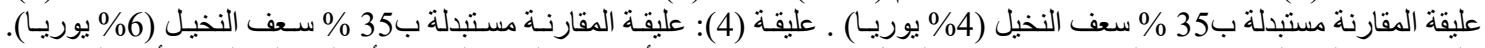

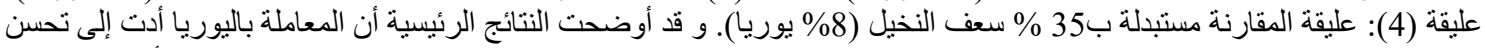

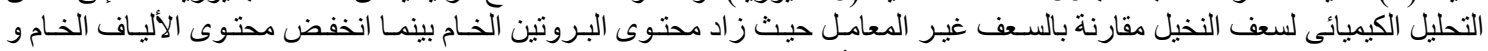

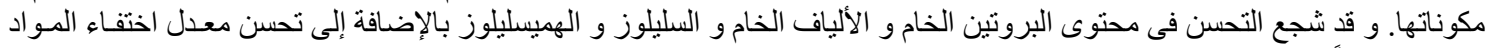

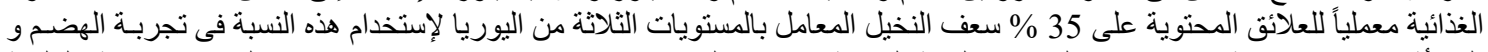

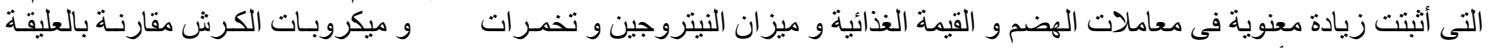

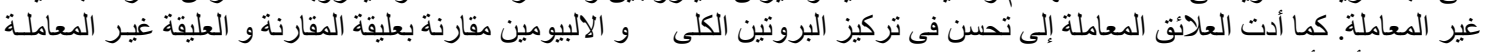

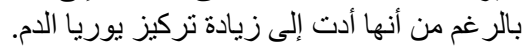

